\title{
Characterization of major and trace minerals, fatty acid composition, and cholesterol content of Protected Designation of Origin cheeses
}

\author{
C. L. Manuelian, S. Currò, M. Penasa, M. Cassandro, and M. De Marchi ${ }^{1}$ \\ Department of Agronomy, Food, Natural Resources, Animals and Environment (DAFNAE), University of Padova, Viale dell'Università 16, \\ 35020 Legnaro (PD), Italy
}

\begin{abstract}
Cheese provides essential nutrients for human nutrition and health, such as minerals and fatty acids (FA). Its composition varies according to milk origin (e.g., species and breed), rearing conditions (e.g., feeding and management), and cheese-making technology (e.g., coagulation process, addition of salt, ripening period). In recent years, cheese production has increased worldwide. Italy is one of the main producers and exporters of cheese. This study aimed to describe mineral, FA, and cholesterol content of 133 samples from 18 commercial cheeses from 4 dairy species (buffalo, cow, goat, and sheep) and from 3 classes of moisture content (hard, <35\% moisture; semi-hard, 35-45\%; and soft, $>45 \%)$. Mineral concentrations of cheese samples were determined by inductively coupled plasma optical emission spectrometry, and FA and cholesterol contents were determined by gas chromatography. Moisture and species had a significant effect on almost all traits: the highest levels of $\mathrm{Na}, \mathrm{Ca}$, and $\mathrm{Fe}$ were found in cheeses made from sheep milk; the greatest level of $\mathrm{Cu}$ was found in cow milk cheese, the lowest amount of $\mathrm{K}$ was found in buffalo milk cheese, and the lowest amount of Zn was found in goat cheeses. In all samples, $\mathrm{Cr}$ and $\mathrm{Pb}$ were not detected (below the level of detection). In general, total fat, protein, and minerals significantly increased when the moisture decreased. Buffalo and goat cheeses had the highest saturated FA content, and sheep cheeses showed the highest content of unsaturated and polyunsaturated FA, conjugated linoleic acid, and n-3 FA. Goat and sheep cheeses achieved higher proportions of minor FA than did cow and buffalo cheeses. Buffalo cheese exhibited the lowest cholesterol level. Our results confirm that cheese mineral content is mainly affected by the cheese-making process, whereas FA profile mainly reflects the FA composition of the
\end{abstract}

Received September 27, 2016.

Accepted January 4, 2017.

${ }^{1}$ Corresponding author: massimo.demarchi@unipd.it source milk. This study allowed the characterization of mineral and FA composition and cholesterol content and revealed large variability among different commercial cheeses.

Key words: goat, sheep, conjugated linoleic acid (CLA), dairy products

\section{INTRODUCTION}

Cheese supplies essential nutrients for human nutrition in the form of proteins, bioactive peptides, AA, fat, fatty acids (FA), vitamins, and minerals (Walther et al., 2008; FAO, 2013). Cheese is suitable for lactoseintolerant individuals because, $94 \%$ of the lactose is washed out with the serum during cheese making, and the rest is fermented to lactic acid (Walther et al., 2008; Law and Tamime, 2011; FAO, 2013). Bioactive peptides, released from milk protein during cheese ripening, are multifunctional components with beneficial effects on cardiovascular, nervous, gastrointestinal, and immune systems (Korhonen and Pihlanto, 2006; Walther et al., 2008). Minerals and vitamins supplied by cheese are important for healthy bones and teeth (Walther et al., 2008; Bonjour et al., 2009). About 60 to $70 \%$ of Ca intake comes from milk and dairy products, with cheese being the main source in adults (Bonjour et al., 2009). Cheese usually contains between 20 and $35 \%$ fat, which contributes to the flavor and texture of the product (Walther et al., 2008). Specific SFA are involved in cell regulation and gene expression (Walther et al., 2008), n-3 FA produce anti-inflammatory eicosanoids (DeFilippis and Sperling, 2006), and CLA have shown health benefits (Walther et al., 2008). However, a detailed profile of mineral and FA contents, which could help consumers in purchasing decisions, is not listed on cheese labels.

Manufacturing cheese is a way to add value to raw milk and increase the shelf life of milk. Cheese composition depends on the milk's microbiological and chemical composition, the cheese-making technology, ripening time, and cheese factory conditions (De Marchi et al., 2008; Formaggioni et al., 2015). Milk protein and 
fat contents vary greatly according to species, breed, season, health status, stage of lactation, and animal diet (Palmquist, 2006; Martini et al., 2008; Walther et al., 2008; Bland et al., 2015). In addition, breed differences have been observed in milk for titratable acidity, freezing point, casein content, total $\mathrm{Ca}$, total $\mathrm{P}$, and colloidal P (Petrera et al., 2016). The pasteurization of the milk before cheese making could affect AA profile and vitamin content (FAO, 2013). The type of starter culture used might modify the total content of protein, fat, and ash, and FA profile of the cheese, due to the different activity and specificity of proteolytic and lipolytic enzymes (Taboada et al., 2015; Lešić et al., 2016). Because of dehydration, protein and fat contents increase during ripening time (Walther et al., 2008; Taboada et al., 2015), and dehydration also affects mineral concentration (FAO, 2013); for example, $\mathrm{K}$ and $\mathrm{Mg}$ concentration decreases and Se concentration increases during ripening (FAO, 2013). Demineralization of curd depends on the pre-acidification of milk, and the $\mathrm{pH}$ of whey at drainage (Lucey and Fox, 1993). However, the increase of some minerals is a result of the salt added during the manufacturing process, such as polyphosphates and $\mathrm{NaCl}$ (Bonjour et al., 2009).

In recent years, cheese production has increased worldwide, particularly in the European Union $(+2.35 \%)$, United States $(+2.83 \%)$, and Australia $(+5.45 \%)$ (CLAL, 2016). Europe produces nearly 52\% of the world's cheese (FAO, 2013) and, among European countries, Italy $\left(1.009 \times 10^{6} \mathrm{t}\right)$ is the third largest cheese producer after Germany $\left(2.320 \times 10^{6} \mathrm{t}\right)$ and France $\left(1.779 \times 10^{6} \mathrm{t}\right)(\mathrm{CLAL}, 2016)$. A large amount of Italian milk production $\left(11.633 \times 10^{6} \mathrm{t}\right.$ in 2014) is destined to cheese making (CLAL, 2016). About $80 \%$ of Italian cheeses are made from cow milk, and the remaining $20 \%$ are from sheep, goat, buffalo, and mixed milks. More than $40 \%$ of cheeses achieve the Protected Designation of Origin (PDO) according to European Regulation 1151/2012 (European Union, 2012; CLAL, 2016), and France, Italy, and Spain have the greatest number of PDO cheeses. For PDO cheeses, European and local legislation specify the rules for manufacturing process, from feeding and animal management to milk origin and aging, in order to protect the quality standard. Mozzarella, Grana Padano, Parmigiano Reggiano, Pecorino, Gorgonzola, and Provolone are the main exported Italian cheeses, with France, Germany, and the United States being the main destination countries (CLAL, 2016). Moreover, considering that the volume of milk destined for cheese manufacturing is growing worldwide in several European countries such as Italy, France, Ireland, and Estonia, several studies have been carried out on milk technological traits and the potential for their genetic improvement (Pretto et al., 2013; Tiezzi et al., 2013; De Marchi et al., 2014; Visentin et al., 2015).

To our knowledge, no studies have characterized the mineral, FA, and cholesterol contents of a wide range of commercial cheeses. Therefore, this study aims to describe and provide detailed information about minerals, FA, and cholesterol content of several PDO cheeses sourced from the Italian retail market.

\section{MATERIALS AND METHODS}

\section{Sample Collection}

A total of 133 cheeses were purchased from Italian stores from July to October 2015. Samples were randomly selected according to store availability and consumers' preferences. Cheeses produced using milk from more than one dairy species were not considered in the present study. Cheese varieties in the study included 11 PDO and 1 Traditional Specialties Guaranteed (TSG) cheeses made from cow milk, 1 PDO from water buffalo milk, 1 Robiola-type cheese from goat milk, and 1 Pecorino-type cheese from sheep milk (Table 1). In addition, 3 cosmopolitan cow milk cheeses (Cheddar, Maasdam, and pasta filata) were included as reference cheeses for the different moisture contents. The main characteristics of the 18 varieties of commercial cheeses included in the study are summarized in Table 1. A cheese variety could be prepared with milk from different dairy species, raw or pasteurized milk, whole or partially skim milk, and different ripening times (Table 1), conferring diversity within each type. Given that the present study was focused on commercial samples, specific feeding and animal management information was not available. However, PDO and TSG cheeses represent geographically linked production with specific animal production systems and requirements in terms of breed, diet, and farming conditions (Bertoni et al., 2001), and specific cheese manufacturing technologies regulated by the European Union and local authorities reported in public and approved guidelines. For example, for Parmigiano Reggiano PDO cheese, cows have to be fed primarily fodder from a defined geographical area and silages are forbidden (European Union, 2009). Cheese samples were transported in portable refrigerators at $4^{\circ} \mathrm{C}$ to the food laboratory of the Department of Agronomy, Food, Natural Resources, Animals and Environment of the University of Padova (Legnaro, Italy), and homogenized with a knife mill (Retsch Grindmix GM200; Retsch GmbH \& Co, Haan, Germany) after removing $1.5 \mathrm{~cm}$ from the rind, when required. To prevent moisture loss, grated samples were kept at $4^{\circ} \mathrm{C}$ in sealed plastic bags until analysis, which was carried out within $24 \mathrm{~h}$ of sample delivery. 


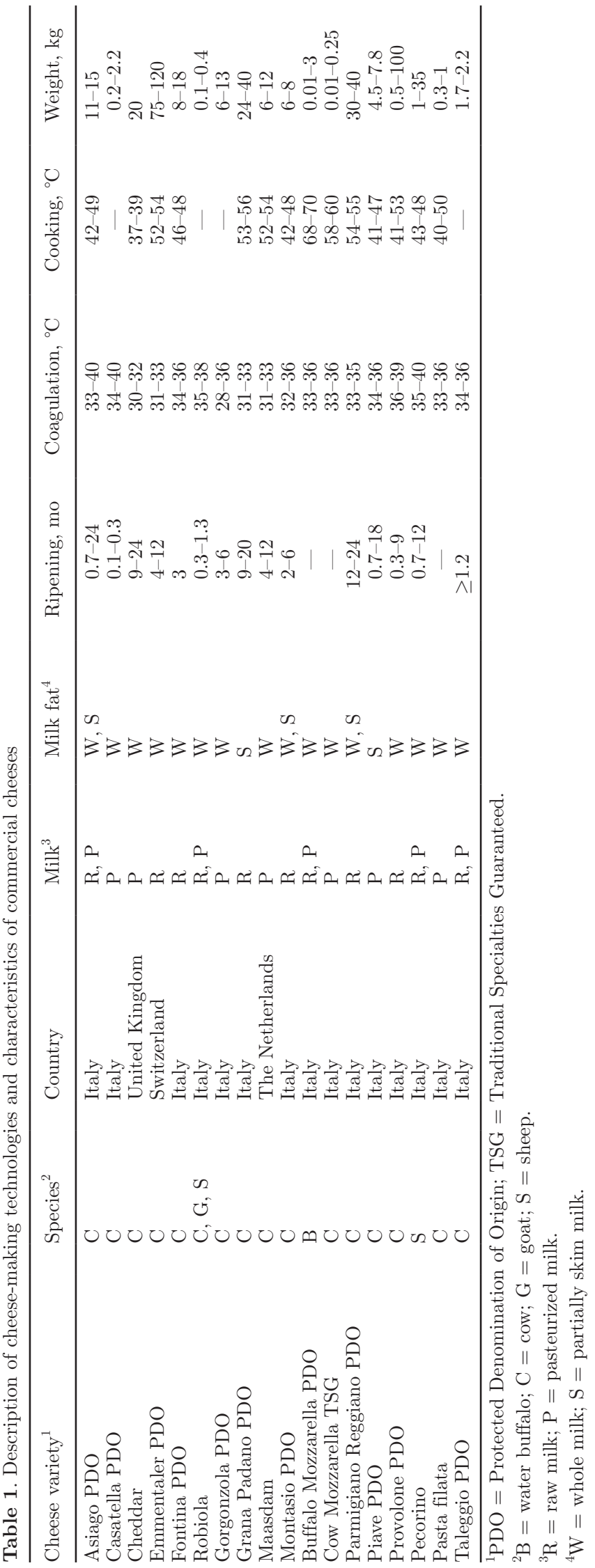

\section{Cheese Chemical Analyses}

Determination of Moisture, Protein, and Cholesterol Content. Cheese moisture and protein contents were determined using a FoodScan Dairy Analyzer (Foss, Electric A/S, Hillerød, Denmark) calibrated with the Foss Artificial Neural Networks Dairy Calibration. Cholesterol content was obtained according to Fletouris et al. (1998) with a capillary column GC system (model GC-15A, Shimadzu Corp., Kyoto, Japan). Regarding moisture content, cow PDO and TSG cheese samples were classified as hard $(<36 \%$ water content), semi-hard (36-45\% water content), or soft (>45\% water content; CLAL, 2016). Consequently, Asiago PDO samples were classified as hard or semihard cheeses. Reference cheeses were assigned to each category regarding average moisture content: Cheddar for hard, Maasdam for semi-hard, and pasta filata for the soft category.

Determination of Minerals Composition. Major mineral (Ca, Na, P, S, K, and $\mathrm{Mg}$ ) and trace mineral ( $\mathrm{Zn}, \mathrm{Fe}, \mathrm{Se}, \mathrm{Cu}, \mathrm{Cr}$, and $\mathrm{Pb}$ ) contents were determined after mineralization with nitric acid in closed vessels by a microwave system (Ethos 1600 Milestone S.r.l., Sorisole, Italy) using an inductively coupled plasma optical emission spectrometer Ciros Vision EOP (ICPOES; Spectro Analytical Instruments GmbH, Kleve, Germany). The ICP-OES was used to determine Ca at $317.933 \mathrm{~nm}, \mathrm{Na}$ at $589.592 \mathrm{~nm}, \mathrm{P}$ at $178.287 \mathrm{~nm}, \mathrm{~S}$ at $182.034 \mathrm{~nm}, \mathrm{~K}$ at $766.941 \mathrm{~nm}, \mathrm{Mg}$ at $285.213 \mathrm{~nm}, \mathrm{Zn}$ at $213.856 \mathrm{~nm}$, Fe at $259.941 \mathrm{~nm}$, Se at $196.090 \mathrm{~nm}$, Cu at $324.754 \mathrm{~nm}, \mathrm{Cr}$ at $220.353 \mathrm{~nm}$, and $\mathrm{Pb}$ at $220.353 \mathrm{~nm}$. Instrument operating parameters were optimized for acid solution, and calibration standards were matched with $5 \% \mathrm{HNO}_{3}$ (vol/vol) solution using $65 \% \mathrm{HNO}_{3} \mathrm{Su}-$ prapur (100441, Merck, Darmstadt, Germany). Operating conditions of the ICP-OES were sample aspiration rate of $2 \mathrm{~mL} / \mathrm{min}$, plasma power $1,350 \mathrm{~W}$, coolant flow $11 \mathrm{~L} / \mathrm{min}$, auxiliary flow $0.60 \mathrm{~L} / \mathrm{min}$, nebulizer flow 0.75 $\mathrm{L} / \mathrm{min}$, and integration time of $28 \mathrm{~s}$. The calibration solutions for each mineral were prepared from singleelement solutions (Inorganic Ventures, Christiansburg, VA) in a concentration range between 0 and $100 \mathrm{mg} / \mathrm{L}$.

Determination of FA Composition. Lipids were extracted following the accelerated solvent extraction method by ASE 200 (Dionex Corp., Sunnyvale, CA) with hexane:isopropanol (3:2) as solvent. Percentage of total fat content was obtained after solvent evaporation. The FA were methylated following an internal method adapted from Christie (1993) with $\mathrm{CH}_{3} \mathrm{ONa}$ as catalyst. After methylation, $n$-heptane and potassium carbonate were added. The fatty acid methyl esters solution was centrifuged at $693 \times g$ for $10 \mathrm{~min}$ at $10^{\circ} \mathrm{C}$ and transferred to a $1.5-\mathrm{mL}$ vial for GC analysis, which 
was performed using an Agilent 7820A GC System (Agilent Technologies, Santa Clara, CA) equipped with an automatic sampler G4567A (Agilent Technologies) and flame-ionization detector. An Omegawax capillary GC column (24136 Supelco; Sigma-Aldrich, Castle Hill, Australia), 30-m long, 0.25-mm inner diameter, and $0.25-\mu \mathrm{m}$ film thickness, was used. The carrier gas was hydrogen at a constant flow rate at $100^{\circ} \mathrm{C}$ with an average speed of $30 \mathrm{~cm} / \mathrm{s}$. A split injection sleeve was used. The injector and detector temperature was set at $250^{\circ} \mathrm{C}$. Oven temperature was initially $50^{\circ} \mathrm{C}$ for $2 \mathrm{~min}$, and then increased at $4^{\circ} \mathrm{C} / \mathrm{min}$ to $220^{\circ} \mathrm{C}$ and held for $18 \mathrm{~min}$. The individual FA were identified by comparing their retention times with those of a standard FA (FAME mix C4-C24 \#18919-1AMP and octadecadienoic acid conjugated methyl ester; Supelco, Sigma-Aldrich). Peak areas were calculated using GC/MSD ChemStation Software (Agilent Technologies) and expressed as percentage of total identified FA. Thereafter, FA were expressed as absolute concentration ( $\mathrm{g} / 100 \mathrm{~g}$ of cheese), calculated using the following formula: $(\mathrm{FA} \% / 100) \times$ 0.945 (Greenfield and Southgate, 2003).

To display the results, a threshold of $8 \%$ of total identified FA was established to distinguish between major and minor FA. In addition, the following FA groups were obtained by summing individual FA: SFA, which included C4:0, C6:0, C7:0, C8:0, C10:0, C11:0, $\mathrm{C} 12: 0, \mathrm{C} 13: 0$ (iso and anteiso forms), C14:0 (iso and anteiso forms), C15:0 (iso and anteiso forms), C16:0 (iso and anteiso forms), C17:0 (iso and anteiso forms), $\mathrm{C} 18: 0$ (iso and anteiso forms), C19:0, C20:0, C21:0, C22:0, C23:0, and C24:0; MUFA, which included C10:1, C12:1, C14:1 (and isomers), C15:1, C16:1n-9, C16:1n-7, C16:1, C17:1n-7, C18:1 (and isomers), C19:1, C22:1n-9, and C24:1n-9; PUFA, which included C18:2n-6, C18:2 (and isomers), C18:3n-6, C18:3n-3, C20:2n-6, C20:3n-6, C20:3n-3, C20:4n-6, C20:5n-3, C22:2n-6, C22:5n-3, and C22:6n-3; UFA, which was the sum of MUFA and PUFA; CLA, which included geometric isomers of C18:2n-6; n-3, which included C18:3n-3, C20:3n-3, C20:5n-3, C22:5n-3, and C22:6n-3; and n-6, which included C18:2n-6, C18:3n-6, C20:2n-6, C20:3n-6, C20:4n-6, and C22:2n-6.

\section{Statistical Analyses}

Data analysis was carried out by using $\mathrm{R}$ version 3.2.5 (R Core Team, 2016). Mineral, FA, and cholesterol contents were analyzed using a linear model with 2 factors: moisture content of cheese (hard, semi-hard, and soft) and species (buffalo, cow, goat, and sheep). Data followed a normal distribution. Multiple comparisons were done with least significant differences (LSD) with adjusted $P$-values by Student's $t$-test. Values are shown as mean \pm SEM. Significance was declared at $P$ $<0.05$, unless otherwise indicated.

\section{RESULTS}

\section{Cheese Composition by Species and Moisture Categories}

Means of cheese chemical composition and mineral content according to species are reported in Table 2 . Although the "cow" category included several cheese varieties, buffalo, goat, and sheep categories included only one variety of cheese each: buffalo Mozzarella, Robiola-type cheese, and Pecorino-type cheese, respectively. Both moisture and species category had a significant effect on all traits. Sheep cheese had the lowest water and the greatest fat and protein contents, whereas buffalo cheese had the opposite pattern. Total content of major minerals was greater in sheep than in buffalo cheese (Table 2). Mineral distribution was similar among cheeses according to species, with greater levels of $\mathrm{Ca}, \mathrm{Na}$, and $\mathrm{P}$ compared with other major minerals, and much higher Zn content compared with other trace minerals. The high level of $\mathrm{Na}, \mathrm{Ca}$, and $\mathrm{Fe}$ in sheep cheeses was statistically high $(P<0.05)$, as was that of $\mathrm{Cu}$ in cow cheeses. The small amount of $\mathrm{K}$ in buffalo cheeses and $\mathrm{Zn}$ in goat cheeses was also noteworthy $(P$ $<0.05)$. In all samples, $\mathrm{Cr}$ and $\mathrm{Pb}$ were below the level of detection $(<0.002 \mu \mathrm{g} / \mathrm{kg}$; data not shown). Total fat, protein, and mineral contents increased significantly $(P$ $<0.001$; data not shown) when moisture decreased, showing greater levels in hard (Table 3) than in semihard (Table 4) and soft cheeses (Table 5), except for Fe, which was more abundant in semi-hard cheeses.

Average percentage values of FA groups and the most abundant and important individual FA in cheeses from different dairy species are shown in Table 6. Buffalo and goat cheeses had the greatest SFA percentage, and sheep cheeses had the highest UFA, PUFA, CLA, and n-3 percentages. Highest MUFA percentage was observed in cow and sheep cheeses, and the highest n-6 percentage was observed in goat and sheep cheeses (Table 6). The most abundant FA were palmitic acid (C16:0), oleic (C18:1n-9), stearic (C18:0), and myristic (C14:0) acids, which represented, on average, $71 \%$ of the total identified FA (Table 6). Although palmitic acid was more abundant in buffalo cheese, oleic and stearic acids were similar across species categories (Table 6). Overall, percentages of minor FA were greater in goat and sheep cheeses than in buffalo and cow cheeses, particularly for caprylic (C8:0), capric (C10:0), and linoleic (C18:2n-6) acids. Cholesterol content was slightly lower in buffalo than in cow, goat, and sheep cheeses (Table 6). Cheese differed significantly within moisture 
Table 2. Mean (SEM) of moisture, fat, protein ( $\mathrm{g} / 100 \mathrm{~g}$ of cheese), major minerals $(\mathrm{mg} / \mathrm{g}$ of cheese), and trace minerals ( $\mu \mathrm{g} / \mathrm{g}$ of cheese) content of commercial cheeses classified by type of milk used in cheese manufacturing

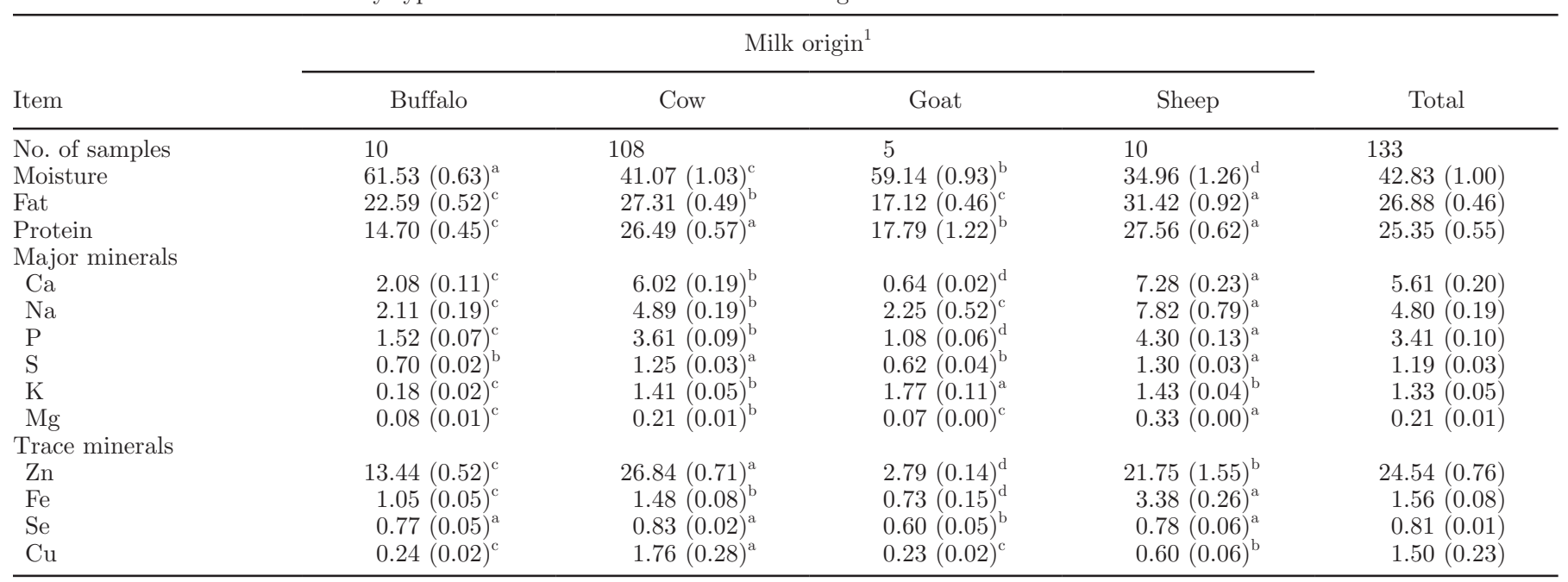

${ }^{\mathrm{a}-\mathrm{d}}$ Values with different superscripts within a row are significantly different $(P<0.05)$.

${ }^{1}$ Buffalo = Buffalo Mozzarella Protected Denomination of Origin (PDO); Cow = Asiago PDO, Casatella PDO, Cheddar, Emmentaler PDO, Fontina PDO, Gorgonzola PDO, Grana Padano PDO, Montasio PDO, Cow Mozzarella Traditional Specialties Guaranteed, Parmigiano Reggiano PDO, Piave PDO, Provolone PDO, pasta filata, Taleggio PDO; Goat = Robiola cheese; Sheep = Pecorino cheese.

categories and within species categories. Fatty acid and cholesterol content were more abundant in hard (Table 7) and semi-hard (Table 8) cheeses than in soft cheeses (Table 9).

\section{Characterization of PDO Cheese Varieties from Cow Milk}

Hard Cheese Composition. The mean contents of fat and protein for the cheeses ranged from 28.45 to $33.37 \%$ and from $27.67 \%$ to $34.01 \%$, respectively (Table 3). The highest variability for fat content was observed in Montasio and highest variability for protein in Asiago (Table 3). The mineral composition profile was similar across hard cheeses varieties, and we detected variability of 45 and $99 \%$ for $\mathrm{Fe}$ and $\mathrm{Cu}$, respectively. The highest $\mathrm{Na}$ content was in Asiago cheese, the highest Fe content in Piave, and the highest $\mathrm{Cu}$ content was in Parmigiano Reggiano and Grana Padano cheeses.

Table 3. Mean (SEM) of moisture, fat, protein ( $\mathrm{g} / 100 \mathrm{~g}$ of cheese), major minerals $(\mathrm{mg} / \mathrm{g}$ of cheese), and trace minerals ( $\mu \mathrm{g} / \mathrm{g}$ of cheese) content of hard (moisture $<36 \%$ ) cow Protected Denomination of Origin (PDO) cheeses and Cheddar cheese

\begin{tabular}{|c|c|c|c|c|c|c|c|}
\hline \multirow[b]{2}{*}{ Item } & \multicolumn{5}{|c|}{ PDO cheeses } & \multirow[b]{2}{*}{$\begin{array}{c}\text { Total } \\
\text { PDO cheeses }\end{array}$} & \multirow[b]{2}{*}{ Cheddar } \\
\hline & Asiago & $\begin{array}{l}\text { Grana } \\
\text { Padano }\end{array}$ & Montasio & $\begin{array}{c}\text { Parmigiano } \\
\text { Reggiano }\end{array}$ & Piave & & \\
\hline No. of samples & 7 & 10 & 5 & 10 & 5 & 37 & 4 \\
\hline Moisture & $30.47(3.90)$ & $32.06(2.47)$ & $33.37(1.36)$ & $30.58(1.24)$ & $28.45(2.91)$ & $31.26(3.01)$ & $35.52(2.10)$ \\
\hline Fat & $30.21(2.13)$ & $27.89(1.18)$ & $29.90(3.53)$ & $31.37(2.64)$ & $33.50(2.22)$ & $30.87(0.54)$ & $36.16(5.63)$ \\
\hline Protein & $30.46(2.25)$ & $34.21(1.60)$ & $27.67(1.19)$ & $34.01(1.95)$ & $31.57(1.58)$ & $31.49(3.23)$ & $26.59(0.92)$ \\
\hline \multicolumn{8}{|l|}{ Major minerals } \\
\hline $\mathrm{Na}$ & $7.00(1.10)$ & $5.54(0.45)$ & $5.89(1.20)$ & $4.85(0.61)$ & $5.70(0.32)$ & $5.66(1.02)$ & $5.29(1.00)$ \\
\hline $\mathrm{P}$ & $4.43(0.30)$ & $4.76(0.29)$ & $4.12(0.16)$ & $4.42(0.23)$ & $4.51(0.19)$ & $4.38(0.44)$ & $3.42(0.18)$ \\
\hline $\mathrm{S}$ & $1.44(0.13)$ & $1.64(0.14)$ & $1.35(0.07)$ & $1.49(0.11)$ & $1.51(0.11)$ & $1.47(0.18)$ & $1.15(0.06)$ \\
\hline $\mathrm{K}$ & $2.11(0.41)$ & $1.62(0.06)$ & $1.79(0.11)$ & $1.59(0.10)$ & $1.77(0.09)$ & $1.70(0.30)$ & $1.26(0.14)$ \\
\hline $\mathrm{Mg}$ & $0.27(0.03)$ & $0.29(0.02)$ & $0.25(0.01)$ & $0.28(0.02)$ & $0.28(0.00)$ & $0.27(0.03)$ & $0.20(0.01)$ \\
\hline \multicolumn{8}{|l|}{ Trace minerals } \\
\hline $\mathrm{Zn}$ & $33.55(2.30)$ & $36.59(2.81)$ & $30.63(1.73)$ & $33.93(2.30)$ & $35.32(0.94)$ & $33.42(3.92)$ & $25.11(2.12)$ \\
\hline
\end{tabular}


Table 4. Mean (SD) of moisture, fat, protein ( $\mathrm{g} / 100 \mathrm{~g}$ of cheese), major minerals $(\mathrm{mg} / \mathrm{g}$ of cheese), and trace minerals ( $\mu \mathrm{g} / \mathrm{g}$ of cheese) content of semi-hard (moisture between 36 and 45\%) cow Protected Denomination of Origin (PDO) cheeses and Maasdam cheese

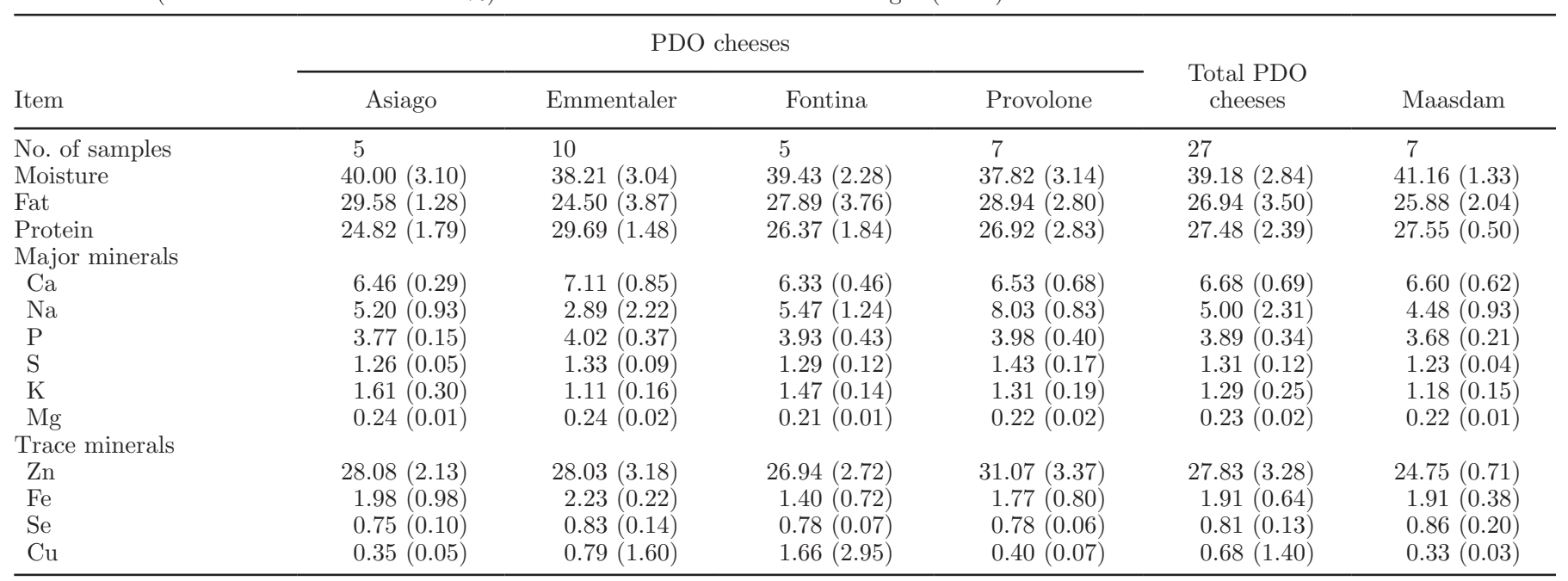

The proportion of major and minor FA was similar across cheese varieties (71 and $13 \%$, respectively; Table 7). Piave had a greater amount of SFA, UFA, and MUFA than other hard cheeses, whereas Parmigiano Reggiano cheese had the greatest amounts of PUFA, CLA, and n-3 (Table 7). The greatest variability was observed for CLA (29\%) and for n-3 (26\%). Finally, cholesterol level was similar across cheese varieties and ranged from 0.07 (Grana Padano and Montasio) to 0.09 $\mathrm{g} / 100 \mathrm{~g}$ of cheese (Asiago; Table7).

Semi-Hard Cheese Composition. The mean contents of fat and protein ranged from 24.50 to $29.58 \%$ and from 24.82 to $29.69 \%$, respectively (Table 4 ). The greatest variability for minerals (above $34 \%$ ) was observed for $\mathrm{Na}, \mathrm{Fe}$, and $\mathrm{Cu}$. Provolone cheese had the greatest amount of $\mathrm{Na}$ and $\mathrm{Zn}$ (Table 4), and Fontina had the greatest amount and variability of $\mathrm{Cu}$ (Table 4).

Major and minor FA relative contents were similar to those of hard cheeses. All 4 cheeses showed similar composition in terms of FA groups, especially between Asiago and Provolone, and slightly lower for Emmentaler (Table 8 ). Variability above $20 \%$ between cheeses was observed for CLA, n-3, n-6, and linoleic acid. Cholesterol content was similar across all semi-hard cheeses (Table 8) with values that ranged from 0.07 (Provolone) to $0.09 \mathrm{~g} / 100 \mathrm{~g}$ of cheese (Asiago).

Soft Cheese Composition. The mean contents of fat and protein ranged from 16.11 to $27.65 \%$ and from 15.66 to $19.73 \%$, respectively (Table 5 ). Soft cheeses

Table 5. Mean (SD) of moisture, fat, protein ( $\mathrm{g} / 100 \mathrm{~g}$ of cheese), major minerals $(\mathrm{mg} / \mathrm{g}$ cheese), and trace minerals ( $\mu \mathrm{g} / \mathrm{g}$ of cheese) content of soft (moisture $>45 \%$ ) cow Protected Denomination of Origin (PDO) and Traditional Specialties Guaranteed (TSG) cheeses, and pasta filata cheese

\begin{tabular}{|c|c|c|c|c|c|c|}
\hline Item & $\begin{array}{l}\text { Casatella } \\
\text { PDO }\end{array}$ & $\begin{array}{l}\text { Gorgonzola } \\
\text { PDO }\end{array}$ & $\begin{array}{c}\text { Cow Mozzarella } \\
\text { TSG }\end{array}$ & $\begin{array}{l}\text { Taleggio } \\
\text { PDO }\end{array}$ & $\begin{array}{l}\text { Total PDO } \\
\text { cheeses }\end{array}$ & Pasta filata \\
\hline No. of samples & 5 & 9 & 10 & 6 & 30 & 3 \\
\hline Protein & $15.66(0.88)$ & $18.69(1.55)$ & $18.23(0.91)$ & $19.73(1.54)$ & $17.83(2.89)$ & $24.59(1.48)$ \\
\hline \multicolumn{7}{|l|}{ Major minerals } \\
\hline $\mathrm{Ca}$ & $2.84(0.40)$ & $3.02(0.67)$ & $3.26(0.39)$ & $2.99(0.61)$ & $2.76(1.14)$ & $5.45(0.58)$ \\
\hline $\mathrm{S}$ & $0.67(0.08)$ & $0.95(0.13)$ & $0.84(0.07)$ & $0.97(0.06)$ & $0.83(0.19)$ & $1.25(0.09)$ \\
\hline $\mathrm{K}$ & $1.33(0.10)$ & $1.70(0.13)$ & $0.30(0.07)$ & $1.77(0.31)$ & $1.03(0.71)$ & $1.02(0.17)$ \\
\hline $\mathrm{Mg}$ & $0.11(0.01)$ & $0.14(0.03)$ & $0.10(0.01)$ & $0.14(0.01)$ & $0.11(0.03)$ & $0.18(0.01)$ \\
\hline \multicolumn{7}{|l|}{ Trace minerals } \\
\hline $\mathrm{Zn}$ & $14.28(2.35)$ & $17.26(3.77)$ & $18.75(2.23)$ & $14.79(2.47)$ & $15.22(5.83)$ & $26.39(3.06)$ \\
\hline $\mathrm{Fe}$ & $0.66(0.11)$ & $0.79(0.51)$ & $1.33(1.70)$ & $1.11(0.82)$ & $1.01(0.87)$ & $1.35(0.43)$ \\
\hline $\mathrm{Se}$ & $0.87(0.24)$ & $0.71(0.13)$ & $0.75(0.10)$ & $0.82(0.23)$ & $0.76(0.17)$ & $0.90(0.20)$ \\
\hline
\end{tabular}


Table 6. Mean (SEM) of groups, major and minor fatty acids (FA, $\%$ of total identified FA), and cholesterol content (g/100 g of cheese) of commercial cheeses classified by type of milk used in cheese manufacturing

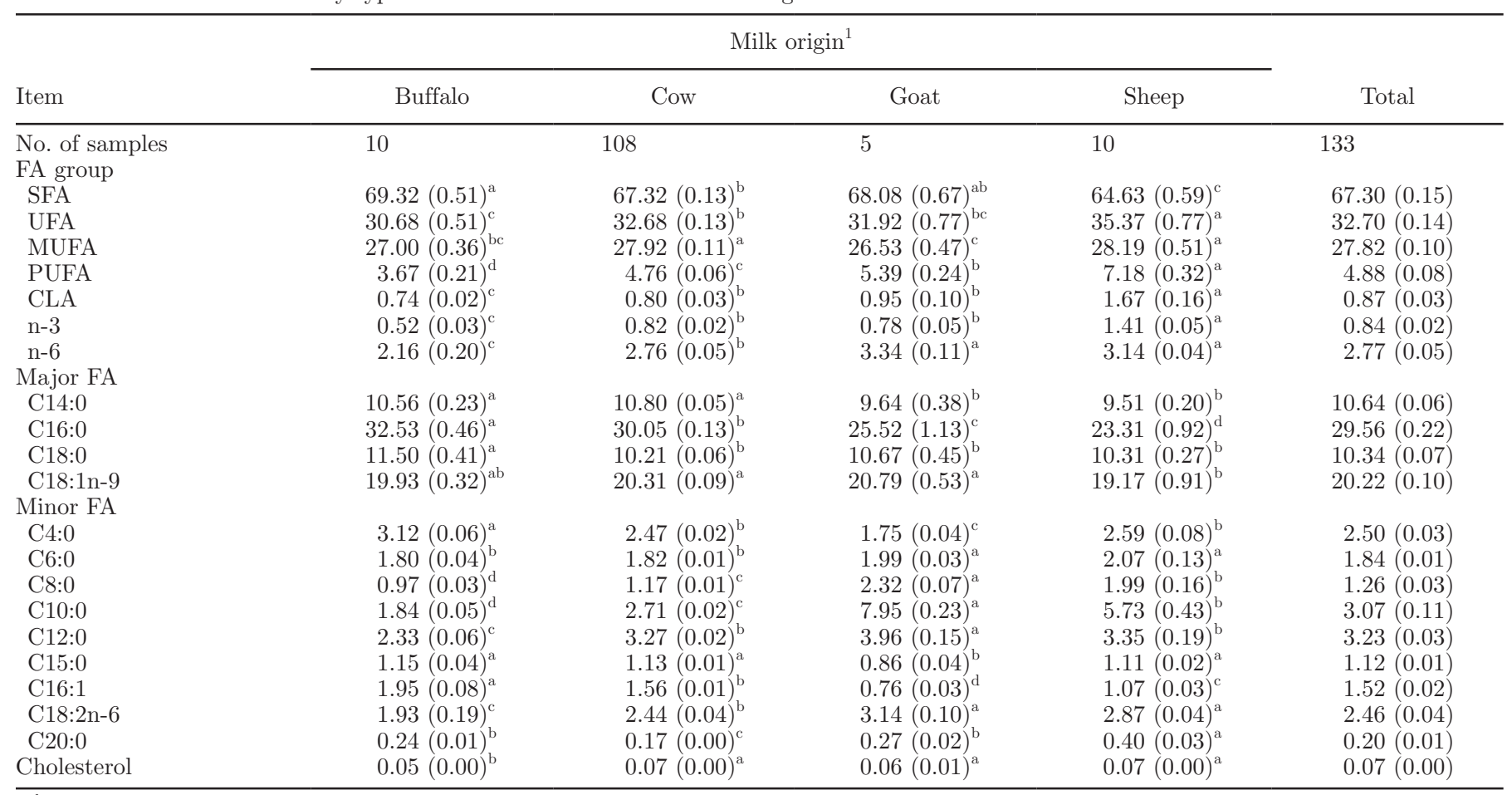

${ }^{\mathrm{a}-\mathrm{d}}$ Values with different superscripts within a row are significantly different $(P<0.05)$.

${ }^{1}$ Buffalo = Buffalo Mozzarella Protected Denomination of Origin (PDO); Cow = Asiago PDO, Casatella PDO, Cheddar, Emmentaler PDO, Fontina PDO, Gorgonzola PDO, Grana Padano PDO, Montasio PDO, Cow Mozzarella Traditional Specialties Guaranteed, Parmigiano Reggiano PDO, Piave PDO, Provolone PDO, pasta filata, Taleggio PDO; Goat = Robiola cheese; Sheep = Pecorino cheese.

showed wide variability for all minerals analyzed, especially for $\mathrm{Cu}, \mathrm{Zn}$, and $\mathrm{Fe}$ (Table 5). Cow Mozzarella, Gorgonzola, and Casatella cheeses showed the widest variability for $\mathrm{Fe}, \mathrm{Zn}$, and $\mathrm{Cu}$, respectively (Table 5). The highest $\mathrm{K}$ content was observed in Taleggio and Gorgonzola, whereas the lowest value was found in cow Mozzarella (Table 5). Copper content was lowest in Casatella (Table 5). The content of $\mathrm{Na}$ was higher in Taleggio cheese, and that of Fe was higher in Taleggio and cow Mozzarella cheese (Table 5).

Fatty acids amounts varied from 19 to $46 \%$, with a wider variation for CLA and capric acid. The greatest variation in CLA and capric acid was observed within Gorgonzola and Casatella cheeses, respectively. Gorgonzola and cow Mozzarella cheeses exhibited the greatest and lowest contents of all FA groups, respectively (Table 9). The lowest n-3 and n-6 levels were detected in cow Mozzarella. Major FA were more abundant in Gorgonzola than in other soft cheeses, whereas the lowest values were obtained in cow Mozzarella cheese (Table 9). Regarding minor FA, the lowest contents were generally found for cow Mozzarella, and the greatest contents for Gorgonzola. Finally, cholesterol content was similar across all cheese varieties, rang- ing between 0.04 (cow Mozzarella) and $0.08 \mathrm{~g} / 100 \mathrm{~g}$ of cheese (Taleggio).

\section{DISCUSSION}

\section{Gross Chemical Composition and Mineral Content of Cheese}

Differences in cheese gross composition (moisture, fat, and protein contents) observed across dairy species are due not only to species, but also to technological processes involved in cheese manufacturing. RaynalLjutovac et al. (2008) have indicated that cheese gross composition is mainly related to the manufacturing process. In addition, Lešić et al. (2016) observed an effect of different starters cultures on protein, fat, and ash contents. Cheese manufacturing involves milk dehydration and concentration of fat, caseins, and some minerals (Law and Tamime, 2011), thus moisture is a confounding variable. In our study, differences in moisture across cheeses were related to the collected data set. For example, cheeses in the buffalo category had almost twice the water content of sheep cheeses because buffalo included only Mozzarella cheese, which is a soft 
Table 7. Mean (SD) of groups, major and minor fatty acids (FA), and cholesterol (g/100 g of cheese) content of hard (moisture $<35 \%)$ cow Protected Denomination of Origin (PDO) cheeses and Cheddar cheese

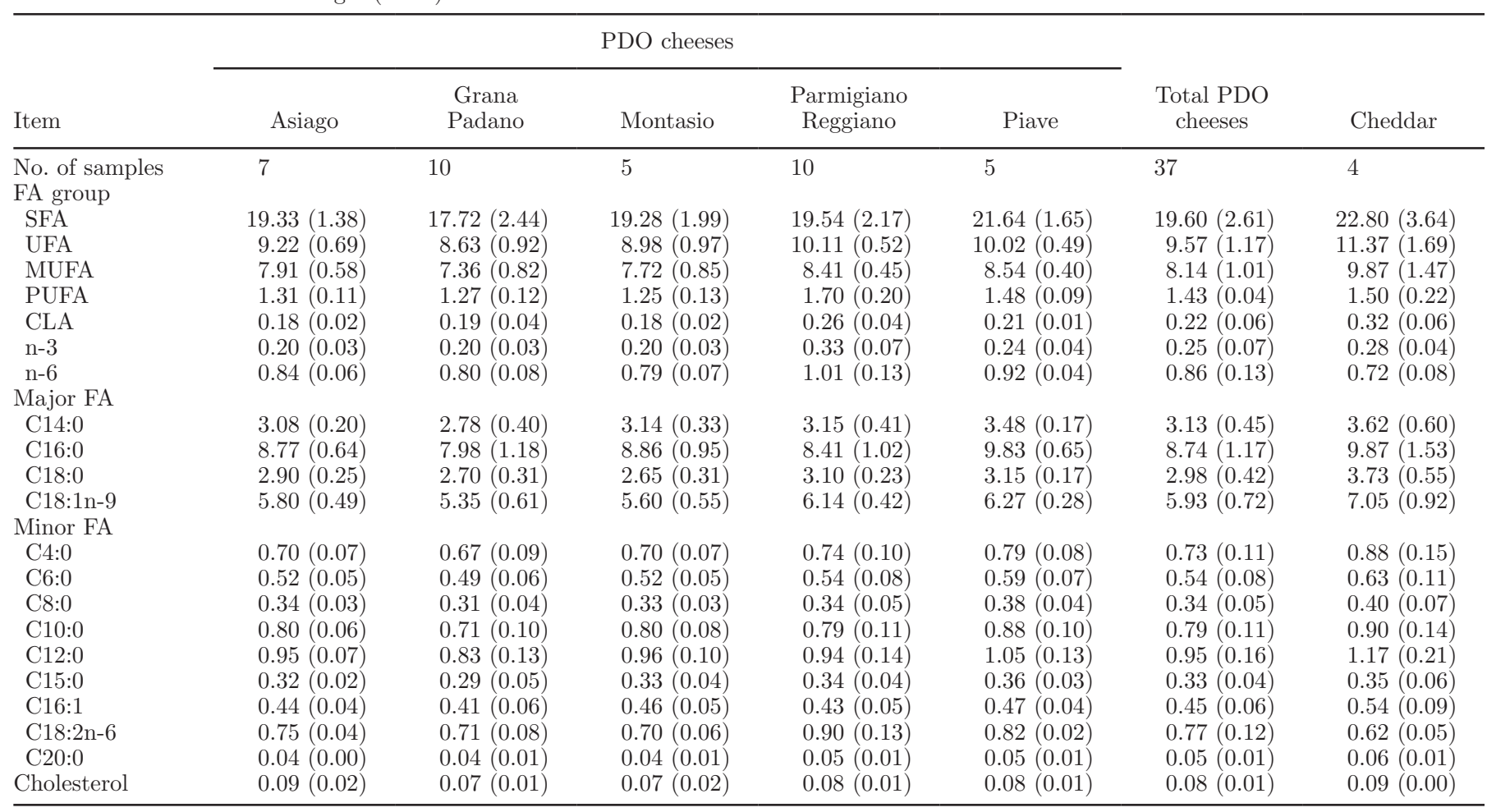

Table 8. Mean (SD) of groups, major and minor fatty acids (FA), and cholesterol ( $\mathrm{g} / 100 \mathrm{~g}$ of cheese) content of semi-hard (moisture between 35 and $45 \%$ ) cow Protected Denomination of Origin (PDO) cheeses and Maasdam cheese

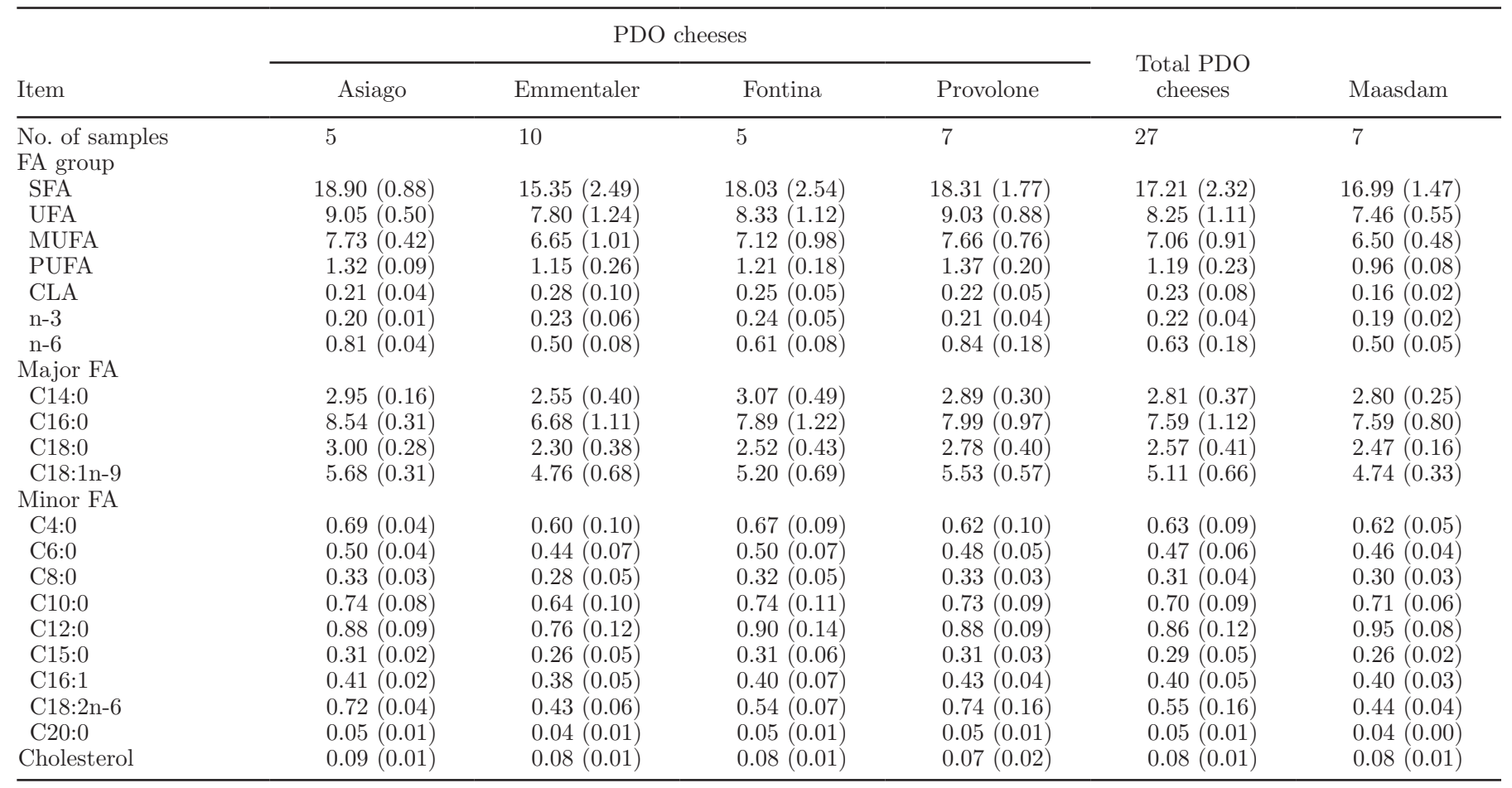


unripened product, whereas sheep mainly included hard or semi-hard Pecorino cheeses. The goat category also had high moisture, mainly because it included only Robiola-type cheese, a soft product.

Differences in milk mineral composition among animal species and breeds are widely recognized to be small (Martin-Hernandez et al., 1992; FAO, 2013; Petrera et al., 2016). Only differences in $\mathrm{P}, \mathrm{Zn}$, and $\mathrm{Cu}$ contents in cheese have been related to milk composition before cheese making in French (Lucas et al., 2006) and Spanish cheeses (Martin-Hernandez et al., 1992). On the other hand, the technological process of cheese making could increase mineral content because of the concentration effect, the addition of salts $(\mathrm{NaCl}, \mathrm{KCl})$, and contamination from the use of metallic instruments during cheese manufacturing (Moreno-Rojas et al., 1994, 1995; Coni et al., 1996; Gambelli et al., 1999; Bonjour et al., 2009; Pecorari et al., 2009). Iron weights and galvanized sheets, respectively, have been suggested as sources of Fe and $\mathrm{Zn}$ in cheese (Moreno-Rojas et al., 1994), and the curdling cutter machine and traditional copper containers as the source of $\mathrm{Cu}$ (Moreno-Rojas et al., 1994; Coni et al., 1996). This could explain the high $\mathrm{Cu}$ levels in Parmigiano Reggiano and Grana Padano, 2 varieties with similar cheese-making processes (Pretto et al., 2013) that use copper tanks (Pecorari et al., 2009). The technological process could also decrease the mineral content due to the solubility of the minerals, the association with whey proteins, $\mathrm{pH}$ during coagulation, grain size, or pressing (i.e., being eliminated with the serum; Martin-Hernandez et al., 1992; Moreno-Rojas et al., 1995; García et al., 2006; Law and Tamime, 2011). A decrease of $\mathrm{pH}$ (from 6.2 to 5.3) in Mozzarella leads to a decrease in mineral content, and the use of different starter cultures or acids can affect mineral concentration (Jana and Mandal, 2011). For example, citric acid is a better chelating agent than lactic acid (Ekholm et al., 2000). Cheeses from the present study were free of $\mathrm{Pb}$ and $\mathrm{Cr}$; however, some authors have detected $\mathrm{Pb}$ in cheese because of environmental contamination throughout the making process (Zurera-Cosano et al., 1994; Coni et al., 1996; Elbarbary and Hamouda, 2013; Meshref et al., 2014). Because of these factors, we do not know if differences observed in mineral content are related to species.

\section{Fatty Acid and Cholesterol Composition of Cheese}

Several authors have reported differences in FA profile across cow, sheep, and goat cheeses (Lucas et al., 2008; Prandini et al., 2011; Lešić et al., 2016), the variability of which mainly depends on milk fat composition (Lucas et al., 2006); up to $75 \%$ of the variance of some FA has been attributed to species (Lucas et al., 2008). De Marchi et al. (2008) reported a breed effect on FA profile of Casolet and Grana Trentino cheeses.

Table 9. Mean (SD) of groups, major and minor fatty acids (FA), and cholesterol ( $\mathrm{g} / 100 \mathrm{~g}$ of cheese) content of soft (moisture $>45 \%$ ) cow Protected Denomination of Origin (PDO) and Traditional Specialties Guaranteed (TSG) cheeses, and pasta filata cheese

\begin{tabular}{|c|c|c|c|c|c|c|}
\hline Item & $\begin{array}{c}\text { Casatella } \\
\text { PDO }\end{array}$ & $\begin{array}{l}\text { Gorgonzola } \\
\text { PDO }\end{array}$ & $\begin{array}{c}\text { Cow Mozzarella } \\
\text { TSG }\end{array}$ & $\begin{array}{l}\text { Taleggio } \\
\text { PDO }\end{array}$ & $\begin{array}{l}\text { Total PDO } \\
\text { cheeses }\end{array}$ & Pasta filata \\
\hline No. of samples & 5 & 9 & 10 & 6 & 30 & 3 \\
\hline \multicolumn{7}{|l|}{ FA groups } \\
\hline SFA & $15.53(1.77)$ & $17.63(1.24)$ & $10.31(0.81)$ & $16.87(1.04)$ & $14.39(3.00)$ & $15.75(1.57)$ \\
\hline UFA & $7.81(0.93)$ & $8.50(0.84)$ & $4.92(0.45)$ & $8.39(0.51)$ & $6.86(1.56)$ & $7.62(0.57)$ \\
\hline MUFA & $6.76(0.80)$ & $7.16(0.84)$ & $4.25(0.38)$ & $7.17(0.48)$ & $5.89(1.33)$ & $6.62(0.43)$ \\
\hline PUFA & $1.04(0.18)$ & $1.34(0.25)$ & $0.67(0.08)$ & $1.22(0.08)$ & $0.97(0.29)$ & $1.00(0.14)$ \\
\hline CLA & $0.15(0.02)$ & $0.21(0.16)$ & $0.13(0.02)$ & $0.16(0.01)$ & $0.16(0.08)$ & $0.17(0.01)$ \\
\hline$n-3$ & $0.17(0.03)$ & $0.22(0.04)$ & $0.11(0.03)$ & $0.17(0.02)$ & $0.15(0.05)$ & $0.18(0.03)$ \\
\hline n-6 & $0.65(0.14)$ & $0.81(0.08)$ & $0.37(0.05)$ & $0.81(0.07)$ & $0.59(0.20)$ & $0.56(0.13)$ \\
\hline \multicolumn{7}{|l|}{ Major FA } \\
\hline C14:0 & $2.39(0.27)$ & $2.80(0.25)$ & $1.63(0.14)$ & $2.70(0.20)$ & $2.24(0.51)$ & $2.53(0.18)$ \\
\hline C16:0 & $7.18(0.70)$ & $7.91(0.80)$ & $4.74(0.45)$ & $7.52(0.49)$ & $6.47(1.49)$ & $7.01(0.83)$ \\
\hline C18:0 & $2.48(0.42)$ & $2.71(0.34)$ & $1.52(0.12)$ & $2.73(0.20)$ & $2.27(0.54)$ & $2.39(0.26)$ \\
\hline C18:1n-9 & $4.99(0.64)$ & $5.13(0.61)$ & $3.13(0.29)$ & $5.22(0.31)$ & $4.33(0.92)$ & $4.87(0.26)$ \\
\hline \multicolumn{7}{|l|}{ Minor FA } \\
\hline $\mathrm{C} 4: 0$ & $0.55(0.09)$ & $0.58(0.09)$ & $0.40(0.02)$ & $0.59(0.03)$ & $0.53(0.14)$ & $0.60(0.05)$ \\
\hline C6:0 & $0.39(0.06)$ & $0.45(0.05)$ & $0.28(0.02)$ & $0.44(0.03)$ & $0.38(0.07)$ & $0.44(0.04)$ \\
\hline C8:0 & $0.25(0.04)$ & $0.29(0.03)$ & $0.18(0.01)$ & $0.29(0.02)$ & $0.25(0.07)$ & $0.28(0.02)$ \\
\hline C10:0 & $0.57(0.09)$ & $0.70(0.05)$ & $0.39(0.03)$ & $0.68(0.06)$ & $0.61(0.28)$ & $0.65(0.05)$ \\
\hline C12:0 & $0.69(0.10)$ & $0.86(0.06)$ & $0.47(0.04)$ & $0.81(0.07)$ & $0.65(0.17)$ & $0.78(0.08)$ \\
\hline C15:0 & $0.25(0.03)$ & $0.30(0.02)$ & $0.17(0.02)$ & $0.28(0.02)$ & $0.24(0.06)$ & $0.26(0.03)$ \\
\hline C16:1 & $0.37(0.04)$ & $0.40(0.05)$ & $0.25(0.03)$ & $0.38(0.03)$ & $0.34(0.10)$ & $0.39(0.02)$ \\
\hline C18:2n-6 & $0.58(0.13)$ & $0.72(0.07)$ & $0.33(0.04)$ & $0.73(0.06)$ & $0.53(0.18)$ & $0.50(0.12)$ \\
\hline C20:0 & $0.04(0.01)$ & $0.04(0.01)$ & $0.03(0.00)$ & $0.04(0.00)$ & $0.04(0.01)$ & $0.04(0.00)$ \\
\hline Cholesterol & $0.06(0.01)$ & $0.07(0.01)$ & $0.04(0.01)$ & $0.08(0.00)$ & $0.06(0.01)$ & $0.05(0.01)$ \\
\hline
\end{tabular}


These differences in FA profile have been used to detect addition of (adulteration with) cow milk in goat and sheep cheeses (Iverson and Sheppard, 1989; Aguilar et al., 2014). Lucas et al. (2006) attributed the differences in percentages of caprylic and myristic acids to the technological process. We observed greater contents of PUFA and short- and medium-chain FA in sheep and goat cheeses than in cow cheeses, in agreement with several other studies (Park et al., 2007; Lucas et al., 2008; Raynal-Ljutovac et al., 2008; Prandini et al., 2011; Aguilar et al., 2014; Lešić et al., 2016). In accordance with Prandini et al. (2011), we determined that sheep cheeses had the highest CLA and the lowest oleic acid contents. The greater oleic acid content in goat than in cow cheese, and the greater butyric, myristic, and palmitic acid contents in cow than in goat cheese in the current study were consistent with the results of Lucas et al. (2008). In addition, the greater n-6 to n-3 ratio in goat compared with cow and sheep cheeses was in agreement with Aguilar et al. (2014). On the other hand, we observed similar CLA percentages in goat as in cow cheeses, in contrast to Van Nieuwenhove et al. (2009), and a similar percentage of oleic acid in cow and goat cheeses, a higher linoleic acid percentage in goat than in cow cheeses, and a similar MUFA percentage in cow than in sheep cheeses, which was in contrast to the results of Prandini et al. (2011).

Cholesterol differences among cheeses have been attributed to milk composition (Park et al., 2007; Gómez-Cortés et al., 2015), and De Marchi et al. (2008) reported a breed effect on cholesterol in Vezzena cheese. Differences in cholesterol level have been also reported for several goat cheeses produced in the United States (Park, 2000) and in Turkish cheeses (Donmez et al., 2005). The lower cholesterol content in buffalo milk cheeses than in cow milk cheeses could result from the lower cholesterol content in buffalo milk (Ahmad et al., 2013).

\section{Composition of PDO Cheese Varieties from Cow Milk}

Given that buffalo, goat, and sheep categories included only one type of cheese (buffalo Mozzarella, Robiola, and Pecorino cheese, respectively), we can compare the composition reported in Table 1 and Table 6 for those species with the composition of the other cow milk cheese varieties included in the study. Compared with the present study, Sameen et al. (2008) reported lower moisture content for buffalo $(50.49 \pm 0.91 \%)$ and cow Mozzarella (52.49 $\pm 0.41 \%)$, lower fat (17.13 \pm $0.45 \%)$ and greater protein $(15.07 \pm 0.67 \%)$ for buffalo Mozzarella, and similar fat and lower protein (14.78 \pm $0.78 \%$ ) for cow Mozzarella. Results from the present work showed greater fat and lower moisture content in buffalo than in cow Mozzarella, in agreement with Sameen et al. (2008), and greater protein content in cow than in buffalo Mozzarella, which is in contrast to the results of Sameen et al. (2008).

Cow milk has similar mineral content to buffalo milk (FAO, 2013); however, we detected greater mineral contents in Mozzarella made from cow milk compared with that in buffalo. We hypothesized that the cheesemaking process could explain the variation. Gambelli et al. (1999) reported different mineral content in the same varieties of commercial Italian cheeses, but no agreement exists among studies about average mineral content of dairy products because mineral content can change according to the analytical method (Lante et al., 2006). However, we obtained orders of mineral content in Italian cheese varieties similar to those of Gambelli et al. (1999) for $\mathrm{Na}$ (Provolone > Grana Padano > Gorgonzola > Emmentaler > cow Mozzarella), K (Gorgonzola $>$ Grana Padano $>$ Provolone $>$ Emmentaler $>$ cow Mozzarella), and Zn (Grana Padano > Provolone $>$ Emmentaler $>$ Gorgonzola $\approx$ cow Mozzarella). Nevertheless, we reported higher Mg in Grana Padano than in Provolone, and a greater Ca concentration in Emmentaler than in Provolone, Gorgonzola, and cow Mozzarella than did Gambelli et al. (1999).

We detected a greater percentage of SFA and lower percentage of UFA and PUFA in buffalo than in cow Mozzarella, which agrees with FA milk composition of these species (Ménard et al., 2010). However, we observed a similar percentage of C14:0 between Mozzarella cheeses of both species and a greater percentage of C18:0 in buffalo than cow Mozzarella, which is in contrast to the findings of Ménard et al. (2010). Prandini et al. (2007), analyzing commercial Italian cheeses, suggested that use of propionic bacteria in production of Emmentaler caused the higher CLA content compared with Grana Padano. Our greater percentage of C18:2n-6, long-chain FA, and PUFA, and lower percentage of medium-chain FA in Gorgonzola than in cow Mozzarella, agree with Prandini et al. (2011), who attributed the differences between fresh cow cheese and Gorgonzola to the technological process.

\section{CONCLUSIONS}

Our results contribute to the characterization of the most widely consumed PDO cheeses and show the importance of several factors in cheese nutritional composition. The differences described support the theory that gross composition (moisture, fat, and protein) and mineral composition are mainly affected by the technological cheese-making process, whereas FA profile and cholesterol are mainly related to milk composition. Because of the wide variability across cheese varieties, 
determination of mineral, FA, and cholesterol composition for each type of cheese could be interesting from a nutritional point of view.

\section{ACKNOWLEDGMENTS}

The authors thank Luciano Magro and Massimo Cagnin (Department of Agronomy, Food, Natural Resources, Animals and Environment, University of Padova) for technical support.

\section{REFERENCES}

Aguilar, C., R. Vera, C. Ugalde, S. Rodríguez, and I. Briones. 2014. A comparative study of the fatty acid profiles in commercial sheep cheeses. Grasas Aceites 65:e048.

Ahmad, S., F. M. Anjum, N. Huma, A. Sameen, and T. Zahoor. 2013. Composition and physico-chemical characteristics of buffalo milk with particular emphasis on lipids, proteins, minerals, enzymes and vitamins. J. Anim. Plant Sci. 23:62-74.

Bertoni, G., L. Calamari, and M. G. Maianti. 2001. Producing specific milks for specialty cheeses. Proc. Nutr. Soc. 60:231-246.

Bland, J. H., A. S. Grandison, and C. C. Fagan. 2015. The effect of blending Jersey and Holstein- Friesian milk on composition and coagulation properties. Int. J. Dairy Technol. 68:3-6.

Bonjour, J.-P., L. Guéguen, C. Palacios, M. J. Shearer, and C. M. Weaver. 2009. Minerals and vitamins in bone health: The potential value of dietary enhancement. Br. J. Nutr. 101:1581-1596.

Christie, W. W. 1993. Preparation of ester derivatives of fatty acids for chromatographic analysis. Pages 68-111 in Advances in Lipid Methodology-2. W.W. Christie, ed. Oil Press, Dundee, UK.

CLAL. 2016. Il mercato del latte. Accessed Jun. 24, 2016. http:// www.clal.it/.

Coni, E., A. Bocca, P. Coppolelli, S. Caroli, C. Cavalluccic, and M. T. Marinucci. 1996. Minor and trace element content in sheep and goat milk and dairy products. Food Chem. 57:253-260.

De Marchi, M., G. Bittante, R. D. Zotto, C. Dalvit, and M. Cassandro. 2008. Effect of Holstein Friesian and Brown Swiss breeds on quality of milk and cheese. J. Dairy Sci. 91:4092-4102.

De Marchi, M., V. Toffanin, M. Cassandro, and M. Penasa. 2014. Invited review: Mid-infrared spectroscopy as phenotyping tool for milk traits. J. Dairy Sci. 97:1171-1186.

DeFilippis, A. P., and L. S. Sperling. 2006. Understanding omega-3's. Am. Heart J. 151:564-570.

Donmez, M., A. K. Secki, O. Sagdic, and B. Simsek. 2005. Chemical characteristics, fatty acid compositions, conjugated linoleic acid contents and cholesterol levels of some traditional Turkish cheeses. Int. J. Food Sci. Nutr. 56:157-163.

Ekholm, P., L. Virkki, M. Ylinen, L. Johansson, and P. Varo. 2000. Effects of natural chelating agents on the solubility of some physiologically important mineral elements in oat bran and oat flakes. Cereal Chem. 77:562-566.

Elbarbary, H. A., and A. F. Hamouda. 2013. Variations in some heavy metals' level during processing of soft cheese. Food Meas. 7:194198.

European Union. 2009. Council Regulation (EC) No 510/2006 "Parmigiano Reggiano" EC No: IT-PDO-0317-0016-26.7.2007. Off. J. Eur. Union. OJ C87/17.

European Union. 2012. Regulation (EU) No 1151/2012 of the European Parliament and of the Council of 21 November 2012 on quality schemes for agricultural products and foodstuffs. Off. J. Eur. Union. OJ L343/1.

FAO. 2013. Milk and Dairy Products in Human Nutrition. E. Muehlhoff, A. Bennett, and D. McMahon ed. FAO, Rome, Italy.

Fletouris, D. J., N. A. Botsoglou, I. E. Psomas, and A. I. Mantis. 1998 Rapid determination of cholesterol in milk and milk products by direct saponification and capillary gas chromatography. J. Dairy Sci. 81:2833-2840.

Formaggioni, P., A. Summer, M. Malacarne, P. Franceschi, and G. Mucchetti. 2015. Italian and Italian-style hard cooked cheeses : Predictive formulas for Parmigiano-Reggiano 24-h cheese yield. Int. Dairy J. 51:52-58.

Gambelli, L., P. Belloni, G. Ingrao, L. Pizzoferrato, and G. P. Santaroni. 1999. Minerals and trace elements in some Italian dairy products. J. Food Compos. Anal. 12:27-35.

García, M. I. H., P. P. Puerto, M. F. Baquero, E. R. Rodríguez, J. D. Martín, and C. D. Romero. 2006. Mineral and trace element concentrations of dairy products from goats' milk produced in Tenerife (Canary Islands). Int. Dairy J. 16:182-185.

Gómez-Cortés, P., E. Viturro, M. Juárez, and M. A. De La Fuente. 2015. Alternative to decrease cholesterol in sheep milk cheeses. Food Chem. 188:325-327.

Greenfield, H., and D. A. T. Southgate. 2003. Food Composition Data Production: Production, Management and Use. 2nd ed. B. A. Burlingame and U. R. Charrondiere, ed. FAO, Rome, Italy.

Iverson, J., and A. Sheppard. 1989. Detection of adulteration in cow, goat, and sheep cheeses utilizing gas-liquid chromatographic fatty acid data. J. Dairy Sci. 72:1707-1712.

Jana, A. H., and P. K. Mandal. 2011. Manufacturing and quality of Mozzarella cheese: A review. Int. J. Dairy Sci. 6:199-226.

Korhonen, H., and A. Pihlanto. 2006. Bioactive peptides: Production and functionality. Int. Dairy J. 16:945-960.

Lante, A., G. Lomolino, M. Cagnin, and P. Spettoli. 2006. Content and characterisation of minerals in milk and in Crescenza and Squacquerone Italian fresh cheeses by ICP-OES. Food Contr. 17:229-233.

Law, B. A., and A. Y. Tamime, eds. 2011. Technology of Cheesemaking. 2nd ed. John Wiley and Sons, Oxford, UK.

Lešić, T., J. Pleadin, G. Krešić, N. Vahčić, K. Markov, M. Vrdoljak, and J. Frece. 2016. Chemical and fatty acid composition of cow and sheep milk cheeses in a lamb skin sack. J. Food Compos. Anal. 46:70-77.

Lucas, A., E. Rock, C. Agabriel, Y. Chilliard, and J. B. Coulon. 2008. Relationships between animal species (cow versus goat) and some nutritional constituents in raw milk farmhouse cheeses. Small Rumin. Res. 74:243-248.

Lucas, A., E. Rock, J. F. Chamba, I. Verdier-Metz, P. Brachet, and J. B. Coulon. 2006. Respective effects of milk composition and the cheese-making process on cheese compositional variability in components of nutritional interest. Lait 86:21-41.

Lucey, J. A., and P. F. Fox. 1993. Importance of calcium and phosphate in cheese manufacture: A review. J. Dairy Sci. 76:1714-1724.

Martin-Hernandez, C., L. Amigo, P. J. Martin-Alvarz, and M. Juarez. 1992. Differentiation of milks and cheeses according to species based on the mineral content. Z. Lebensm. Unters. Forsch. 194:541-544.

Martini, M., M. Mele, C. Scolozzi, and F. Salari. 2008. Cheese making aptitude and the chemical and nutritional characteristics of milk from Massese ewes and the chemical and nutritional characteristics of milk from Massese ewes. Ital. J. Anim. Sci. 7:419-437.

Ménard, O., S. Ahmad, F. Rousseau, V. Briard-Bion, F. Gaucheron, and C. Lopez. 2010. Buffalo vs. cow milk fat globules: Size distribution, zeta-potential, compositions in total fatty acids and in polar lipids from the milk fat globule membrane. Food Chem. 120:544-551.

Meshref, A. M. S., W. A. Moselhy, and N. E.-H. Hassan. 2014. Heavy metals and trace elements levels in milk and milk products. Food Meas. 8:381-388.

Moreno-Rojas, R., M. A. Amaro-Lopez, R. H. Garcia-Gimeno, and G. Zurera-Cosano. 1995. Effects of Manchego-type cheese-making on contents of mineral elements. Food Chem. 53:435-439.

Moreno-Rojas, R., M. A. Amaro-Lopez, and G. Zurera-Cosano. 1994. Copper, iron and zinc variations in Manchego - type cheese during the traditional cheese - making process. Food Chem. 49:67-72.

Palmquist, D. L. 2006. Milk fat: Origin of fatty acids and influence of nutritional factors thereon. Pages 43-92 in Advanced Dairy Chem- 
istry, Volume 2: Lipids. P. F. Fox and P. L. H. McSweeney, ed. Springer, New York, NY.

Park, Y. W. 2000. Comparison of mineral and cholesterol composition of different commercial goat milk products manufactured in USA. Small Rumin. Res. 37:115-124.

Park, Y. W., M. Juárez, M. Ramos, and G. F. W. Haenlein. 2007. Physico-chemical characteristics of goat and sheep milk. Small Rumin. Res. 68:88-113.

Pecorari, M., G. Gambini, A. Pecorari, F. Masotti, J. A. Hogenboom, L. Pellegrino, S. Ghidini, and M. Malacarne. 2009. L'utilizzo di caldaie di rame o di acciaio: Effetti sulla tecnologia e sulle caratteristiche qualitative del parmigiano-reggiano. Sci. Tecn. Latt. Cas. 60:97-118.

Petrera, F., G. Catillo, F. Napolitano, M. Malacarne, P. Franceschi, A. Summer, and F. Abeni. 2016. New insights into the quality characteristics of milk from Modenese breed compared with Italian Friesian. Ital. J. Anim. Sci. 15:559-567.

Prandini, A., S. Sigolo, and G. Piva. 2011. A comparative study of fatty acid composition and CLA concentration in commercial cheeses. J. Food Compos. Anal. 24:55-61.

Prandini, A., S. Sigolo, G. Tansini, N. Brogna, and G. Piva. 2007. Different level of conjugated linoleic acid (CLA) in dairy products from Italy. J. Food Compos. Anal. 20:472-479.

Pretto, D., M. De Marchi, M. Penasa, and M. Cassandro. 2013. Effect of milk composition and coagulation traits on Grana Padano cheese yield under field conditions. J. Dairy Res. 80:1-5.

R Core Team. 2016. R: A language and environment for statistical computing. The R Project. Vienna, Austria.
Raynal-Ljutovac, K., G. Lagriffoul, P. Paccard, I. Guillet, and Y. Chilliard. 2008. Composition of goat and sheep milk products: An update. Small Rumin. Res. 79:57-72.

Sameen, A., M. Anjum, N. Huma, and H. Nawaz. 2008. Quality evaluation of mozzarella cheese from different milk sources. Pak. J. Nutr. 7:753-756.

Taboada, N., C. Van Nieuwenhove, S. L. Alzogaray, and R. Medina. 2015. Influence of autochthonous cultures on fatty acid composition, esterase activity and sensory profile of Argentinean goat cheeses. J. Food Compos. Anal. 40:86-94.

Tiezzi, F., D. Pretto, M. De Marchi, M. Penasa, and M. Cassandro. 2013. Heritability and repeatability of milk coagulation properties predicted by mid-infrared spectroscopy during routine data recording, and their relationships with milk yield and quality traits. Animal 7:1592-1599.

Van Nieuwenhove, C. P., R. Oliszewski, and S. N. Gonzalez. 2009. Fatty acid composition and conjugated linoleic acid content of cow and goat cheeses from northwest Argentina. J. Food Qual. 32:303-314.

Visentin, G., A. McDermott, S. McParland, D. Berry, O. Kenny, A. Brodkorb, M. Fenelon, and M. De Marchi. 2015. Prediction of bovine milk technological traits from mid-infrared spectroscopy analysis in dairy cows. J. Dairy Sci. 98:6620-6629.

Walther, B., A. Schmid, R. Sieber, and K. Wehr. 2008. Cheese in nutrition and health. Dairy Sci. Technol. 88:389-405.

Zurera-Cosano, G., R. Moreno-Rojas, and M. A. Amaro-Lopez. 1994. Effects of processing on the concentration of lead in Manchego type cheese. Food Addit. Contam. 11:91-96. 